\title{
DEVELOPMENT AND IMPROVEMENT OF THE VALUE'S HAND CRAFTS THROUGH ENTREPRENEURS MANAGEMENT TO THE STUDENT OF VOCATIONAL HIGH SCHOOL IN CIBINONG DISTRICT - BOGOR
}

\author{
Lubban Anwari Alhamidi'), Prasetio Ariwibowo²), Dwi Rorin M.Insana ${ }^{3}$ ) \\ $\left.{ }^{1}, 3\right)$ Language and Art Faculty of Indraprasta University PGRI Jakarta \\ Nangka Street No. 58 C (TB. Simatupang), Tanjung Barat, Jagakarsa - South Jakarta 12530 \\ Email : lubbanalhamidi@yahoo.com, \\ $\left.{ }^{2}\right)$ Faculty of Economic Education University Indraprasta PGRI Jakarta \\ Tengah Highway No. 80, Gedong, Pasar Rebo -East Jakarta 13760 \\ Email : Prasetio.ariwibowo@yahoo.com \\ Email : dwirorin@gmail.com
}

\begin{abstract}
ABSTRAK
Sasaran kegiatan pengabdian masyarakat ini adalah Sekolah Menengah Kejuruan (SMK) di Kecamatan Cibinong dan Citeureup - Kabupaten Bogor. Peserta yang dilibatkan adalahsiswa dan siswi kelas 11, 12, 13. Berdasarkan potensi yang dimiliki, siswa/i sekolah menengah kejuruan memiliki kecenderungan pada program kewirausahaan UMKM yang sangat bervariasi khususnya di sektor industri kreatif. Melalui kegiatan ini akan terbentuk jiwa generasi wirausahawan baru yang memiliki karakter yang baik dan memiliki kemampuan bersaing self competence di era pemerintah yang menggalakkan program entrepreneurship dalam menghadapi Asean Free Trade Assosiation (AFTA) sehingga menjadi bermanfaat bagi para calon pengusaha dan mampu menopang perekonomian secara individu dan nasional. Kegiatan ini dilakukan dengan mendatangi dan melakukan kegiatan workshop mengenai kewirausahaan dan manajemen usaha bagi siswa/i yang berkumpul di aula masing-masing Sekolah Menengah Kejuruan se-Kecamatan Cibinong - Kabupaten Bogor. Pelaksanaan kegiatan pengabdian masyarakat telah berhasil dilaksanakan dengan persentase terhadap perencanaan, proses, hasil berturut-turut 91,3\%; 97,5\%, dan 97,5\% dalam kategori yang sangat baik. Dan dapat diambil kesimpulan bahwa tanggapan para peserta terhadap pelaksanaan kegiatan workshop Kewirausahaan di SMKN 01 PGRI Cibinong dan SMK Bina Harapan Citeureup ini sangat baik. Hal ini terlihat dari indikator kehadiran peserta mencapai $97 \%$ dari jumlah peserta yang ditargetkan tingkat kehadirannya.
\end{abstract}

Kata Kunci : Kewirausahaan, wirausahawan, Self Competence, Workshop, Manajemen Usaha

\section{ABSTRACT}

The target of this community service activity is Vocational High School (SMK) in Cibinong and Citeureup Sub - Bogor Regency. Some Participants involved are students of 11th, 12th, and 13th graders. Based on their potential, vocational school students have a tendency in entrepreneurial program of UMKM which is very varied, especially in creative industry sector. Through this activity will form the soul of a new generation of entrepreneurs who have good character and have the ability to compete for self-competence in the era of government that promote entrepreneurship programs in the face of Asean Free Trade Association (AFTA) so as to be beneficial to prospective entrepreneurs and able to sustain the economy individually and national. This activity is conducted by visiting and conducting workshop on entrepreneurship and business management for students who gathered in the hall of each Vocational High School in Cibinong sub-district, Bogor regency. Implementation of community service activities has been successfully implemented with percentage to the planning, process, the result is $91,3 \% ; 97.5 \%$, and $97.5 \%$ in very good category. And it can be concluded that the responses of the participants to the implementation of the workshop entrepreneurship in SMKN 01 PGRI Cibinong and SMK Bina Harapan Citeureup is very good. This is evident from the attendance indicators of participants reached $97 \%$ of the number of participants who targeted its attendance.

Key words: Entrepreneurship, Entrepreneur, Self Competence, Workshop, Business Management 


\section{PRELIMINARY}

Era Globalization demands maturity in entrepreneurship, because with independence through the ability to do entrepreneurship which is also being encouraged by the government of Indonesia is sustaining the community's need for an independent micro-economic system. Through entrepreneurship development programs that are expected to improve the quality and capacity of these small and medium entrepreneurs we will be able to prepare human resources that have an independent business spirit. The ability and knowledge of small-scaled businesses on management science is lacking, especially in the field of kewirauasahaan through workshops and seminars for prospective entrepreneurs. Although most aspiring entrepreneurs are already or are currently studying formal, but not all have adequate management background to achieve good and true results in accordance with business management norms that have at least a minimum standard. Thus, in the management of their business often experience obstacles. This can be seen from the low interest or desire of prospective entrepreneurs in running their business so that only limited ideals. By providing training, workshops or seminars is expected to be able to provide motivation with the hope that will be useful later on when prospective entrepreneurs run their business. In addition, through the program that will be the author of this inventory is expected to contribute to the participants about the management of their business.

Through the dedication of this society will form the soul of a new generation of entrepreneurs who have good character so as to have the ability to compete for competence to compete in the era of globalization or free market. Given that the government is promoting entrepreneurship programs in the face of the Asean Free Trade Association (AFTA) so that the contributions will be given by these authors will be very useful for prospective entrepreneurs so that their contribution will be able to sustain the economy individually and nationally.

Therefore, need to improve the science of business management and entrepreneurship sciences that for small entrepreneurs (entrepreneurial groups), in developing the business in the future requires an independent soul and a strong character in the face of global competition.

Based on these backgrounds, it is known various problems of partners that the author made acauan in the implementation of community service is:

1. Internal side, given the self-confidence of aspiring entrepreneurs are still very low then the formation of a strong character in doing business should be done effectively and as early as possible. This is because the prospective entrepreneurs must have a strong mental or character because of the multi-business problems are very comprehensive and dynamic. Both in terms of challenges and obstacles in entrepreneurship.

2. External side, the challenges faced by this small business in the form of market conditions that sometimes very difficult to determine the economic value of goods or services produced in the midst of tight business competition conditions with fellow small businesses in the environment and outside the surrounding environment.

Through this community service activity, the writer hopes to reach the target output, among others:

1. Growing other skills (non academic) to students who are still in school and after becoming alumni (non academic) through the soul of independence and skills in entrepreneurship obtained from institutions / schools. 
2. In addition to the students / $\mathrm{i}$ can produce products (goods / services) that have a sale value, products (goods / services) produced can be marketed more widely because it has a better economic value that can be distributed to traditional markets and modern markets.

3. It is expected that students can apply new methods in entrepreneurship by using ERP (Enterprise Resources Planning) method that is to dig their own potential and explore their potential resources to be processed into a more economical value.

\section{LITERATURE REVIEW}

\section{A. Entrepreneurship}

Entrepreneurship is the equivalent of entrepreneurship in English, unternehmer in German, ondernemen in Dutch. While in Indonesia given the name of entrepreneurship. 1 The word entrepreneurship itself actually originated from the French language is "entreprende" which means adventurers, creators, and business managers. The term was first introduced by Richard Cantillon (1755). The term is increasingly popular after being used by economist JB Say (1803) to describe entrepreneurs capable of moving economic resources from lower productivity levels to higher levels and generating more.2 Actually, many experts have expressed an understanding of entrepreneurship based on point of view respectively. However, the essence of a crucial understanding is always present in every sense advanced by these scholars and is fundamental.

1. The concept of Entrepreneurship (Entrepreneurial)

Entrepreneurship is identifying, developing, and bringing these visions into innovative ideas, opportunities, better ways of doing things. The end result of the process is the creation of new ventures that are formed under conditions of risk or uncertainty.

Scarborough and zimmerer in Novian (2012) define entrepreneur: Entrepreneur is a Person who creates a new business in the face of risk and uncertainty with the intention to gain profit and growth by recognizing opportunities and combining the resources needed to exploit opportunities the entrepreneur is who creates a new business in the face and uncertainty for the purpose of achieving profit and growth by indentifying opportunites and assembling the necessary resources to capitalize on those opportunitie).

According to Presidential Instruction No. 4 of 1995 dated June 30, 1995 on the National Movement of Socializing and Entrepreneurship, saying that, "Entrepreneurship is the spirit, attitude, behavior and ability of a person in dealing with businesses and activities that lead to the searching, creating, work, technology and new production by increasing efficiency in order to provide better service and or gain greater benefits ".

An entrepreneur is necessarily required to face the risks or opportunities that arise, and is often associated with creative and innovative actions. Entrepreneurs are people who change the value of resources, labor, materials and other production factors become larger than before and also people who make changes, innovations and new ways. In addition, an entrepreneur exercises a managerial role in his activities, but routine management of ongoing operations is not classified as entrepreneurship when forming an organization, but then performing managerial functions without entrepreneurship, so entrepreneurship can be temporary or conditional.

People who engage in entrepreneurial activities are called entrepreneurs. The question arises why an entrepreneur (entrepreneur) has a different way of thinking than humans in general. They have the motivation of soul-calling, perceptions and emotions that are closely related to values.

Values, attitudes and behavior as superior human beings. Etymologically, entrepreneurship comes from the word wira and effort. Wira means warrior, hero, superior 
man, noble example, brave and great-natured. Business is expensive, works, and does something. So entrepreneur is a fighter or a hero who does something. While epistimologically, entrepreneurship is the value needed to start a business or process in working on a new and something different.

Entrepreneurship in the view of Islam is an aspect of life that is grouped into your problem "amalah, the problem relating to the relationship that is horizontal between humans and will still be accounted later in the hereafter. In the letter of An-Najm verse 39-42 reminds man:

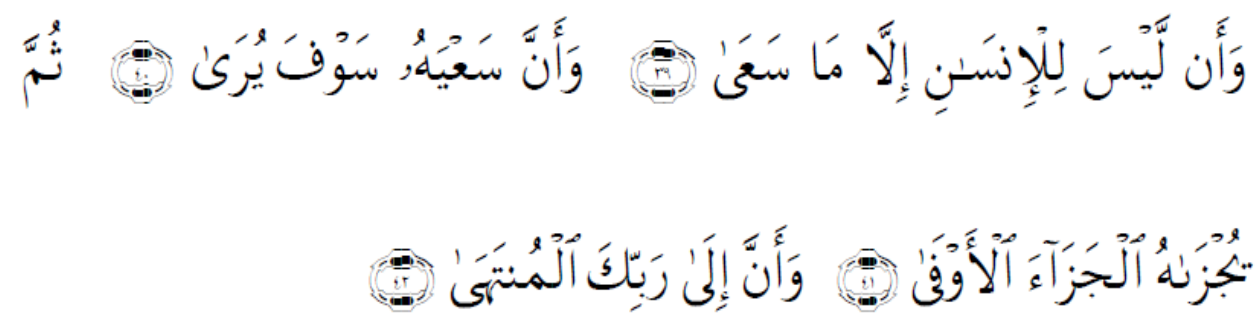

"and that man shall obtain only what he has earned, and verily his efforts shall be shown unto him, and shall be rewarded unto him with the most perfect reward, and verily unto thy Lord is the end (all things) ".(QS. An-Najm verse 39-42)

Trying to work as hard as picking firewood in the forest is more honorable than begging and relying on others. Such is the instruction and direction of the Messenger of Allah to make his people as honorable and respected people, not weak and lazy people.

2. Type and Characteristics of Entrepreneurship

a. Three main types of entrepreneurs are:

1) Entrepreneurial Expert (Craft man)

An expert entrepreneur or an inventor has an idea that wants to develop the production process of the production system, and so on. This skilled entrepreneur is usually someone who works for a big company then decides to quit as an employee and start his own business.

2). The Promoter

The promoter is an individual who had a background job as a sales or marketing who then develop their own company.

3). General Manager

The general manager is an ideal individual who successfully works for a company, he has a lot of expertise in production, marketing, capital and supervision.

Based on the above description the term entrepreneur has a different meaning on everyone because they see this concept from different points of view. However, there are some common aspects contained in the entrepreneurial sense of risk, creativity, efficiency, freedom and reward.

b. Category Entrepreneur / self-employed

According to Ciputra, there are four categories of entrepreneurs, as follows:

1) Business Entrepreneurs

a). Owner entrepreneurs are creators and business owners.

b). Professional entrepreneurs are people who have the power of entrepreneurship but practice it in companies owned by others. 
2). Government Entrepreneurs

A person or group of people who lead and manage state institutions or government agencies with entrepreneurial spirit and competence. For example is Lee Kuan Yew, former Prime Minister of Singapore, he is a leader who manages and grows Singapore with entrepreneurial spirit and competence.

3). Social Entrepreneur

Namely the founders of world-class social organizations that raise public funds to carry out the social tasks they believe in.

4) Academic Entrepreneur

It is an academic who taught or managed educational institutions with the style and style of entrepreneur while still keeping the noble goal of education.

\section{METHODE OF THE IMPLEMENTATION}

This devotional activity is done by visiting the location of the activity. Students gathered in the classroom to get a workshop on entrepreneurship and business management ending with a national seminar for students who gathered in the vocational hall of each Vocational High School in Cibinong sub-district of Bogor Regency, then given material on Economy, Development Economics, Management, and Entrepreneurship. Furthermore, given the description of the results to be gained will be the profit and loss of various business products (goods / services) that will or have been produced. Thus, the students can comprehensively comprehend the business governance in the form of increased sales results, improved welfare, and eliminate the fear of banks and financial institutions and dependence on moneylenders. In addition, it is expected to increase student confidence, in increasing the family income from successful culinary management, will be brought in by a resource person who has successfully run the program. From three months of dedication to the planned community, every one month afterwards is evaluated the success of the activity.

This activity uses the concept of counseling, where participants are given briefing. From the debriefing is expected to produce a mindset, so that participants will not passive but interactive dialogue that finally able to apply what is obtained from the counseling in the form of something valuable and economic value of integrated business management and standardization of simple business accounting.

Table 1

Series of Community Service Activities

\begin{tabular}{|l|l|l|}
\hline No & $\begin{array}{l}\text { Material of Community } \\
\text { Service Activities }\end{array}$ & Interviewees \\
\hline 1 & Concept of Community Service & All Member of Team \\
\hline 2 & The concept of Entrepreneurship & $\begin{array}{l}\text { Dwi Rorin Mauludin Insana, } \\
\text { S.Pi., MM. }\end{array}$ \\
\hline 3 & $\begin{array}{l}\text { The Economics and Concepts of } \\
\text { Integrated } \\
\text { Management Enterprise }\end{array}$ & $\begin{array}{l}\text { Prasetio Ariwibowo S.MB. } \\
\text { MM. }\end{array}$ \\
\hline 4 & $\begin{array}{l}\text { Motivation and Innovation } \\
\text { Personality in Entrepreneurship } \\
\text { is good and right }\end{array}$ & $\begin{array}{l}\text { Lubban Anwari Alhamidi } \\
\text { S.Ag.,MM. }\end{array}$ \\
\hline
\end{tabular}




\begin{tabular}{|l|l|l|}
\hline 5 & Entrepreneurship Workshop & All Member of Team \\
\hline 6 & $\begin{array}{l}\text { Evaluation of Integrated } \\
\text { Management Training Report }\end{array}$ & All Member of Team \\
\hline 7 & Accompaniment & All Member of Team \\
\hline
\end{tabular}

During the process, participants are given the opportunity to communicate directly with the Community Service Team, either in the form of telephone, email, face-to-face (question and answer) directly to the companion who is always in their midst.

The steps taken in this community service are:

1. Step I (Speaker: Lubban Anwari Alhamidi S.Ag., MM.)

Participants are given motivation to have a spirit and entrepreneurial spirit that is high and inherent by changing the paradigm of thinking participants related to entrepreneurship activities. The first step is held for an hour with lecture and discussion methods.

2. Step II (Speaker: Prasetio Ariwibowo S.MB. MM.)

Participants are given knowledge about economics in the form of economic philosophy, uptodate economic conditions and participants are given cases of business management and resolution with the aim that participants have more knowledge about economic conditions, especially economic conditions in Indonesia and participants can increase entrepreneurial knowledge. The second step is held for 1 hour with lecture method and case study.

3. Step III (Speaker: Dwi Rorin Mauludin Insana, S.Pi., MM.)

Training participants are given the opportunity to design new business by creating a simple and visible bussiness plan and then present it in front of the forum to get input from other groups. The third step is held for an hour with lecture, workshop and discussion methods.

Table 2 The Teamwork Composition of AbdiMas Unindra PGRI Jakarta

\begin{tabular}{|l|l|}
\hline \multicolumn{1}{|c|}{ Name } & \multicolumn{1}{|c|}{ Illustration } \\
\hline \begin{tabular}{l|l|} 
Lubban Anwari Alhamidi \\
S.Ag.,MM.
\end{tabular} & $\begin{array}{l}\text { A lecturer of English Language Subject, } \\
\text { History of Teachers' Struggle (SPJG) PGRI, } \\
\text { Education Profession, Student Development, } \\
\text { Entrepreneurship, Basic Depth Science, and } \\
\text { Citizenship Education. }\end{array}$ \\
\hline Prasetio Ariwibowo, S.MB. & $-\begin{array}{l}\text { Experience in research and community } \\
\text { service }\end{array}$ \\
\hline
\end{tabular}




\begin{tabular}{|l|l|l|}
\hline M.M. & $\begin{array}{l}\text { Bank and Financial Institution, History of } \\
\text { Economic Thought and Development } \\
\text { Economics }\end{array}$ \\
& $-\begin{array}{l}\text { Experience in research and community } \\
\text { service }\end{array}$ \\
\hline - & $\begin{array}{l}\text { Experienced in MSME and Banking and } \\
\text { Financial Institutions }\end{array}$ \\
\hline $\begin{array}{l}\text { Dwi Rorin Mauludin } \\
\text { Insana, S.Pi., MM }\end{array}$ & $\begin{array}{l}\text { A lecturer pengampu the course of } \\
\text { introduction of statistics, research methods, } \\
\text { entrepreneurship I and entrepreneurship II } \\
-\end{array}$ \\
& $-\begin{array}{l}\text { Experience in entrepreneurship } \\
\text { - Experience in community service and } \\
\text { research }\end{array}$ \\
\hline
\end{tabular}

\section{RESULTS AND DISCUSSION}

The success rate of community service lies in the practice of various theories that have been given about entrepreneurship by instructors in the form of workshops that have been produced by abdimas participants conducted through direct observation by the instructor through performance appraisal and product results to participants in the preparation, execution and evaluation process in making the creation of functional products of glass glass material with reference to the indicators set by the instructor. The assessment indicator model used to assess process skills is as follows:

Table 3 Scale Value of Functional Production Processing

\begin{tabular}{|l|l|l|c|c|c|}
\hline No & \multirow{2}{*}{ Skills Observed } & \multicolumn{3}{|c|}{ Number of Scale } \\
\cline { 2 - 5 } & $\begin{array}{l}\text { Preparation for (Material selection, } \\
\text { measurement, and Tool setup) }\end{array}$ & & & & \\
\hline 2 & The Use of the correct Equipment & & & & \\
\hline 3 & $\begin{array}{l}\text { Accuracy Steps make functional } \\
\text { product creation }\end{array}$ & & & & \\
\hline 4 & $\begin{array}{l}\text { The Conformity of the final results } \\
\text { presented according to the criteria } \\
\text { that have been applied }\end{array}$ & & & & \\
\hline 5 & $\begin{array}{l}\text { Arranging the equipment after } \\
\text { completion of the activity }\end{array}$ & & & & \\
\hline 6 & Creativity Products & & & & \\
\hline
\end{tabular}




\begin{tabular}{|l|l|l|l|l|l|}
\hline 7 & Product neatness & & & & \\
\hline 8 & Color combinations & & & & \\
\hline & 4 = Very Good, 3 = Good, 2 = Enough, 1 = Less & & \\
\hline
\end{tabular}

Furthermore the final results of the performance appraisal are averaged and converted using the following conversion guidelines:

Table 4

Evaluation of the Result Guidelines Table

\begin{tabular}{|c|c|c|c|}
\hline No. & Additonal & Score & category \\
\hline 1 & $85-100$ & 4 & Very good \\
\hline 2 & $70-84$ & 3 & Good \\
\hline 3 & $55-69$ & 2 & Enough \\
\hline 4 & $<54$ & 1 & less \\
\hline
\end{tabular}

Entrepreneurship workshop activities at SMKN 01 PGRI Cibinong and SMK Bina Harapan Citeureup were held on 28 March - 11 April 2017. This activity started at 09.30 12.00 WIB at SMK Negeri 01 PGRI Cibinong and 14.00 - 17.00 WIB at SMK Bina Harapan Citeureup. This activity begins by gathering participants in the multipurpose hall of each school as a training ground. Target participants 100 people from each school consisting of students of class XI and XII. But the school asked for the training / workshop is only followed by class XII.

First, the instructor (Lubban Anwari Alhamidi) addresses issues related to character formation and the excavation of good and true self potential through lecture and discussion methods. Participants are very enthusiastic about following this activity, and are very interested to understand the shortcomings and advantages they have as well as develop the advantages of self potential that has not been or has been known by the participants in a good and right way.

The Second Event, the instructor (Prasetio Ariwibowo) conveyed about the Economy and Concept of Integrated Business Management through lecture and discussion methods. Participants were very enthusiastic in following this activity, mindset and participants' knowledge become more open and comprehend to understand about uptodate economic condition, philosophy, and technique / concept / system of integrated business management in face of fluctuating economic condition in good way and correct. Participants are very enthusiastic about following this activity, and they are very interested in practicing from the theory they have acquired. Each participant is freed to create the functional creations of glass made from glass, either mimics the examples that have been prepared or create their own creations. Each participant who has completed his product is given the opportunity to create a different pattern according to the one each participant wants.

The result of the workshop on the creation of functional objects from glass made from glass in general can be said to be successful. This can be seen from the percentage of attendance both in SMK Negeri 01 Cibinong which reached the range of $98 \%$ of the total 100 participants expected. Of the participants there were divided into 20 groups consisting of 4-6 
people per group. Based on the planning, processes, and results of practice can be described as follows:

Table 5 Table of Recapitulation of Result of Activity Data Making "Gelas Hias" At SMK Negeri 01 Cibinong - Bogor

\begin{tabular}{|c|c|c|c|c|}
\hline $\begin{array}{c}\text { GROUP } \\
\text { NO. }\end{array}$ & Plaining & Procces & Result & Totally \\
\hline 1 & 4 & 4 & 4 & 12 \\
\hline 2 & 3 & 4 & 4 & 11 \\
\hline 3 & 4 & 4 & 4 & 12 \\
\hline 4 & 4 & 4 & 4 & 12 \\
\hline 5 & 4 & 4 & 4 & 12 \\
\hline 6 & 3 & 4 & 4 & 11 \\
\hline 7 & 3 & 4 & 4 & 11 \\
\hline 8 & 4 & 4 & 4 & 12 \\
\hline 9 & 4 & 4 & 4 & 12 \\
\hline 10 & 4 & 4 & 4 & 12 \\
\hline 11 & 3 & 4 & 4 & 11 \\
\hline 12 & 4 & 4 & 4 & 12 \\
\hline 13 & 3 & 4 & 4 & 11 \\
\hline 14 & 4 & 4 & 4 & 12 \\
\hline 15 & 4 & 4 & 4 & 12 \\
\hline 16 & 3 & 4 & 3 & 10 \\
\hline 17 & 3 & 4 & 4 & 11 \\
\hline 18 & 4 & 4 & 4 & 12 \\
\hline 19 & 4 & 3 & 4 & 11 \\
\hline 20 & 4 & 3 & 3 & 10 \\
\hline Total & 73 & 78 & 78 & \\
\hline$\%$ & $91,3 \%$ & $97,5 \%$ & $97,5 \%$ & $95,43 \%$ \\
\hline
\end{tabular}

Based on the Table we can know that in the planning of making this functional glass "glass product" get the value of $91.3 \%$ in very good category, the process of making the creation of this functional item gets $97.5 \%$ which means very good and in the result stage get the same value that is equal to $97,5 \%$ which means in very good category. From these three results, it can be concluded that the value of handicrafts through entrepreneurial management in Vocational High School students Cibinong District - Bogor managed in accordance with expectations.

Meanwhile, when viewed from the percentage of attendance both in SMK Bina Mandiri Sejahter - Citeureup which reached the range of $97 \%$ of the total number of 100 participants expected. Of the participants there were divided into 20 groups consisting of 4-6 people per group. Based on the planning, processes, and results of practice can be described as follows: 
Table 6 Table of Recapitulation of Result Activity Data Making “Gelas Hias" at SMK Bina Mandiri Sejahtera Citeureup - Bogor

\begin{tabular}{|c|c|c|c|c|}
\hline $\begin{array}{c}\text { Group } \\
\text { No. }\end{array}$ & Plaining & Proccess & Result & Total \\
\hline 1 & 4 & 4 & 4 & 12 \\
\hline 2 & 3 & 4 & 4 & 11 \\
\hline 3 & 4 & 4 & 4 & 12 \\
\hline 4 & 3 & 4 & 3 & 10 \\
\hline 5 & 4 & 4 & 4 & 12 \\
\hline 6 & 3 & 4 & 4 & 11 \\
\hline 7 & 3 & 4 & 4 & 11 \\
\hline 8 & 4 & 4 & 4 & 12 \\
\hline 9 & 3 & 4 & 3 & 12 \\
\hline 10 & 4 & 4 & 4 & 12 \\
\hline 11 & 3 & 4 & 4 & 11 \\
\hline 12 & 4 & 4 & 4 & 12 \\
\hline 13 & 3 & 4 & 4 & 11 \\
\hline 14 & 4 & 4 & 4 & 12 \\
\hline 15 & 4 & 4 & 4 & 12 \\
\hline 16 & 3 & 4 & 3 & 10 \\
\hline 17 & 3 & 4 & 4 & 11 \\
\hline 18 & 4 & 4 & 3 & 12 \\
\hline 19 & 4 & 3 & 4 & 11 \\
\hline 20 & 4 & 3 & 3 & 10 \\
\hline Total & 71 & 78 & 75 & \\
\hline$\%$ & $88,8 \%$ & $97,5 \%$ & $93,8 \%$ & $93,36 \%$ \\
\hline
\end{tabular}

Based on the above table we can know that in planning the manufacture of glass "functional glass" this product get the value of $88.8 \%$ in very good category, the process of making the creation of this functional object gets $97.5 \%$ which means very good and in the stage of the results get the same value that is equal to $93,8 \%$ which means in very good category. From these three results, it can be concluded that the value of handicrafts through entrepreneurship management on Vine Bright Midwifery School students Bina Mandiri Sejahtera Citeureup Bogor managed in accordance with expectations.

Based on the results of Community Service Activities (Abdimas) which have been presented in the results, this activity received a very positive response from the participants, teachers, and principals from SMK Negeri 01 Cibinong and SMK Bina Mandiri Sejahtera Citeureup - Bogor. The participants are very enthusiastic to follow this activity and the results are very good, as well as the teachers who gladly facilitate the smooth activities of this community service activities.

There are several obstacles in the implementation of this abdimas in terms of determining the time because the abdimas is scheduled on the day after the class XII follow the School Final Exam (UAS) and the National Final Exam (UAN) on Thursday, March 30, 
2017 at $08.00 \mathrm{~s} / \mathrm{d} 12.00$ for the implementation at SMK Negeri 01 Cibinong and Tuesday, April 11, 2017 at SMK Bina Mandiri Sejahtera Citeureup. But there is a misunderstanding in the day of abdimas implementation in SMK Bina Mandiri Sejahtera Citeureup, this is because the students of SMK Bina Mandiri Sejahtera Citeureup are doing the Study Tour to Yogyakarta and surrounding areas. So that abdimas activity in SMK Bina Mandiri Sejahtera Citeureup conducted on Wednesday, April 12, 2017 from $13.00 \mathrm{~s} / \mathrm{d} 17.00$.

The "decorative glassware" creations of the participants are made in accordance with expectations, the instructor targets that the participants are able to make handicrafts according to the criteria set by the instructor in terms of size, color, image design, soul and entrepreneurial mindset are good and right, good entrepreneurial management right from the beginning to the end of production and other criteria.

Nevertheless, the very active cooperation of the participants to complete every task, able to be done by the participants with full responsibility and can be embedded in the mind and spirit of each participant's spirit of what they should do after they finish their school in each of them. each school is the majority on wanting to be someone who produces and useful to others is to become a good entrepreneur and right than continuing education to university. This implies that they are very disciplined with time even though they have a lack of understanding and level of intelligence that has been underestimated by the public but they have a great passion for learning to be better people in the future.

\section{Enclosed some photos activity in the workshop Program In vocational High School of SMK PGRI 1 and SMK Mandiri Cibinong :}
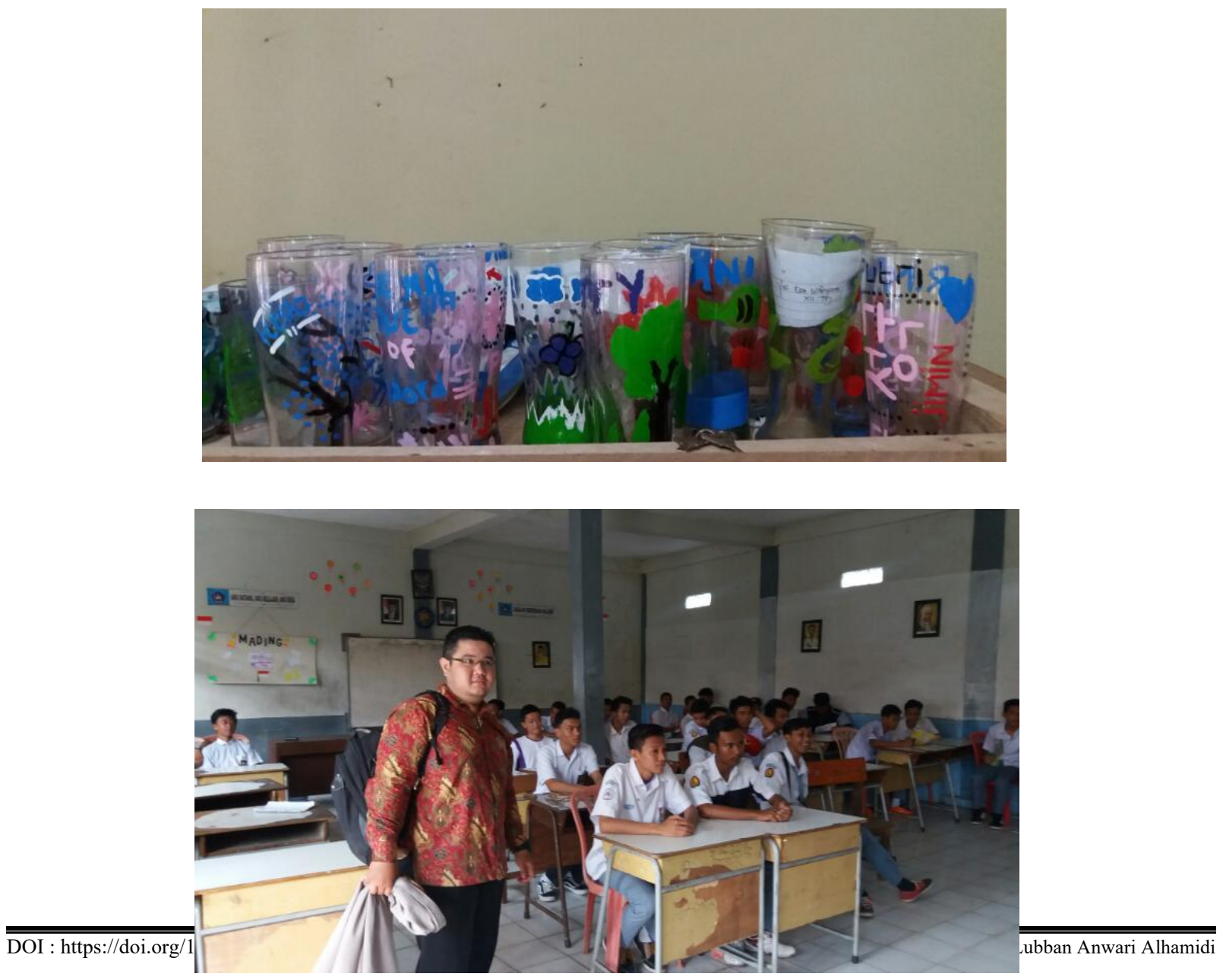

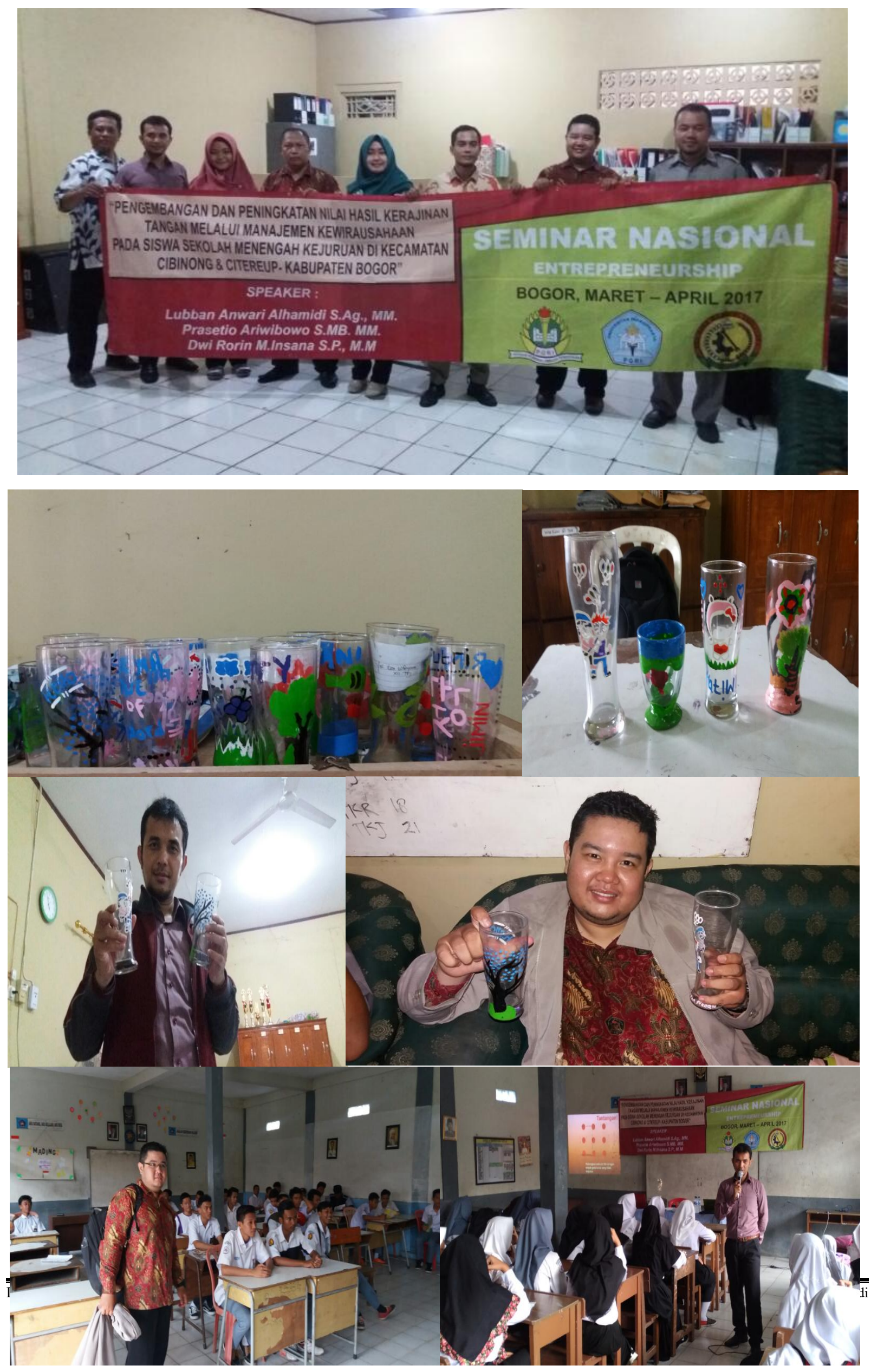


\section{CONCLUSION}

Based on the results and discussion of community service activities that have been described previously, can be drawn the following conclusions:

1. Implementation of community service activities of entrepreneurship workshop at SMKN 01 PGRI Cibinong and SMK Bina Harapan Citeureup which was held on 28 March to 12 April 2017 in the form of "decorative glass" and the development of successful entrepreneurial character has been successfully executed with percentage to planning, the results were $91.3 \% ; 97.5 \%$, and $97.5 \%$ in very good category.

2. Responses of the participants on the implementation of community service activities entrepreneurship workshop at SMKN 01 PGRI Cibinong and SMK Bina Harapan Citeureup is very good. This is evident from the attendance indicators of participants reached $97 \%$ of the number of participants who targeted its attendance. During the event, the participants were very enthusiastic to follow the activities from the beginning to the end of the activity to find out tips to become a good entrepreneur.

\section{REFERENCE}

[1] Novian, Perdana Putra. 2016. Pengaruh Keterampilan Wirausaha Terhadap Kinerja Usaha. Penerbit Universitas Pendidikan Indonesia. Bandung.

[2] Lambing, Peggy dan Charles R. Kuehl, Entrepreneurship, Prentice Hall, Upper Saddle River, 2000.

[3] Zimmerer, Thomas W. dan Norman M. Scarborough. (2004). Pengantar Kewirausahaan dan Manajemen Bisnis Kecil Edisi Bahasa Indonesia. PT. Indeks, Jakarta.

[4] Riyanto, Astim. 2000. Teori Konstitusi. Bandung: Yapemdo

[5] Bygrave, William D. 1994. The Portable MBA in Entrepreneurship. Singapore : John Wileyand Sons, Inc.

[6] Ciputra. (2009). Ciputra Quantum Leap. Entrepreneurship mengubah Masa Depan Bangsa dan Masa Depan Anda. Cetakan ke 4. Jakarta: Elex Media Komputindo.

[7] Suherman, Eman. 2010. Desain Pembelajaran Kewirausahaan. Bandung: Alfa Beta.

[8] Robbins, Stephen P. Dan Coutler, Mary. 2010. Manajemen. Edisi Kesepuluh. Penerbit Erlangga : Jakarta.

[9] Hasibuan, Malayu S.P. 2006. Manajemen Dasar, Pengertian, dan Masalah. Edisi Revisi. Bumi Aksara. Jakarta.

[10] Rangkuti, Freddy. 2009. Strategi Promosi yang Kreatif dan Analisis Kasus Integrated Marketing Communication. Jakarta : PT. GramediaPustakaUtama 